\title{
Comparative Study of Persuasive Directive Speech on Printed and Digital Media Advertising
}

\author{
Muhammad Rohmadi ${ }^{1}$, Chafit Ulya $^{2}$, Keken Wulansari ${ }^{3}$, Ulfa Rizqi Putri ${ }^{4}$, Memet \\ Sudaryanto ${ }^{5}$ \\ \{mamad_r76@staff.uns.ac.id¹, chafit@staff.uns.ac.id², kekenw@student.uns.ac.id², \\ ulfakiky@student.uns.ac.id ${ }^{4}$, memetsudaryanto@gmail.com ${ }^{5}$ \} \\ Universitas Sebelas Maret, Indonesia ${ }^{1234}$ \\ Universitas Jenderal Soedirman, Indonesia ${ }^{5}$
}

\begin{abstract}
Changes in the form of discourse affect messages on the implicature to be conveyed. In advertising discourse, the implicatures conveyed may have various meanings which are not only dominated by persuasion of the invitation to buy the product or service being offered. The pragmatic viewpoint positions language as a complex message, which contains the message and function of the message. This qualitative research explores information from print and online media which is analyzed, described, and compared as a form of implicature data. Metadata were tabulated and sampling was conducted to identify persuasive directive speech on advertisements that have different characteristics. Directive speech acts in advertisements have different implicatures. The dominant function of the speech act from the results of the analysis includes speech containing requests, speech acts of the command directive, speech acts of the prohibited directive, and the function of the speech act of the requesting directive. Advertising has the main function of being persuasive, but the results of the implicative analysis show that the utterances in the advertisement contain commands, prohibitions, and information. Through the use of good persuasive language, advertisers are able to increase the number of visitors who make purchase decisions through digital media. In general, persuasive sentences in advertisements are conveyed creatively and generally, employed rhymes to attract attention and can be easily remembered.
\end{abstract}

Keywords: Persuasive, Pragmatics, Advertisement

\section{Introduction}

Speech act is a person's ability to use language in conveying messages or certain goals from the speaker to the speech partner. Each speaker has different speech acts influenced by the speech partner, situation, message, and the purpose to be conveyed. Every speech act contains implications which constitute a directive speech act assessment that needs to be conducted to determine the forms of language use and what speech strategies can be used in speech participants to reduce the risk or unpleasant consequences of the speech [1]. The language rules of ad text consist of the use of persuasive and imperative statements, the language is concise, and gives a positive impression. From the language rules of the advertisement, it can be seen that the ad text contains persuasive and imperative language, which when examined pragmatically, it is included in directive speech act [2]. 
Pragmatics is the study of language usage in relation to contexts or speech situations. The use of language studied in pragmatic relates to the intent of the utterances spoken. One of the meanings of the utterance in pragmatics can be identified by using implicatures. Advertising as an object of study has a close construct containing persuasive expressions. Ad makers certainly want to attract attention from ad listeners, both buying and using the services of the ad. This persuasion can be shown by words and behavior and attitudes of speakers who are considered to force the listener [3]. Therefore, the implicature as a presupposition is the first step that must be taken to test this persuasive speech. Persuasive expression is a language unit which aims to convince readers or consumers to do something that is desired so as to generate confidence in consumers or readers about advertisements or products that are satisfied. In the pragmatic discourse, persuasion is not just a form but can be internalized in the implicatures conveyed by the speech partners. Pragmatic studies on the external elements of language can determine the meaning of speech in a communication [4]. The interaction between speakers and speech partners can produce implicit meanings as well as explicit meanings. Therefore, it is important in speech act research to see the context that will give strength or illocutionary power to each form of language spoken. The power of this illocution is not only determined by the form of the language, but also strengthened by the emergence of the underlying context.

Illocutionary speech acts can have two purposes, which are informing and ordering the speech partner to do something. Therefore, context is the main indicator in directive speech act utterance. Apart from going through the context, semantic and kinesthetic markers can also be used as markers of directive speech acts. Certain lexicons and particles can have their own effect on speech partners. The findings of intonation, kinesthetic cues, and the use of certain expressions such as ayo (let), hendaknya (should), coba (try) and particles such as lah (Indonesian particle) reducing the illocutionary power of speech, can also be used as markers of certain speech acts. The speech acts of the directive are classified into five types, which are (a) the speech act of the directive instructs the speech partner to act according to what the speaker says, (b) the speech act of the directive requests to politely ask the speech partner to take the action desired by the speaker, (c) the directive speech act suggests that it is used to do something good according to speakers for both parties, (d) the directive advises the interlocutor to remind the interlocutor of something he is going to do, and (e) the speech act of the challenging directive is used to motivate the speech partner to want to do something spoken by speakers [5].

The implicature in this study is not based on the principle of cooperation or maxims and does not have to occur in conversation and does not depend on the specific contexts to interpret it. Communication does not only occur in the form of conversation or direct communication, but it could also be indirect communication. In indirect communication, it can be via telephone, television, radio, or other media. In television and radio, people can get a lot of information because it contains a lot of news to advertisements. Misunderstanding of intent usually occurs because the language used by the speaker contains pragmatic elements. In pragmatic studies, speakers and interlocutors must both know the context of the speech so that the ongoing communication process can run effectively. The language of advertising as an information provider experiences an image process that is performed in the form of creating associations between the products offered with the lifestyle, social stratification, and certain symbols. 


\section{Research Method}

This study is a study which analyzed speech acts in both printed and digital advertising text. Interest in analyzing advertising language was influenced by the languages used in advertisements which are quite diverse and the words used often employ trending and slang words so that they can create more interest to the public. Ads analyzed were distributed data first to determine the sampling to be conducted. After the data was documented in the research metadata, qualitative testing was performed using data instruments in the form of research guidelines and data analysis guidelines. The research method used was the content analysis method, which was by discussing in depth the content contained in the advertising text, both print and digital advertisements.

This research approach was administered qualitatively by collecting descriptive data. In order to test the validity of the data, this study used data validity tests in the form of data source triangulation, method triangulation, and theory triangulation. The research data were collected and identified based on the problems in the study. Then, data reduction was performed starting from data collection to completion [6]. Then, data pre-presentation or data display, verification, and drawing conclusions were also performed. The results of the research were conducted with a focused group discussion with experts, mass media consumers, and practicing lecturers who use linguistic studies.

\section{Results and Discussion}

Various utterances containing the speaker's request for the speech partner to act according to the speaker's will are included in the form of request directive speech act. The use of the request directive speech act is usually accompanied by information about a matter and also an expression of the speaker's desire so that the speech partner does something or so that the speaker gets something from the speech partner. The data findings show the emergence of a speech act that has a purpose, which is the speaker directly asks the feelings of the speech partner. The speaker expresses the speech in order to get an answer in the form of information or an explanation of something that is being asked by the speaker.

This study analyzed advertisements of both products and services in printed and digital media advertisements. Advertisements in printed media were found on pamphlets, billboards, newspapers, posters, and magazines. Each data was described and processed based on the shape and function implicature [7] [8]. Meanwhile, data on digital media was divided into audio and visual which was transcribed into text that had context in the delivery of the advertisement. The speech acts analyzed in the advertisement were the directive of orders, prohibitions, and requests. Each form of speech was grouped based on its purpose and function [9]. Command directive speech acts are utterances in the form of imperative sentences spoken by the speaker so that the speech partner does something according to the speaker's will. Instructional directive speech acts are usually expressed by speakers whose authority is higher than the speech partners. Furthermore, a high tone and a loud voice are signs of sentences with this speech act. In speech acts, the directive commands the form of a sentence or verb to perform an order or the necessity to conduct an action [10].

Meanwhile, the instructional directive speech act is spoken by the speaker with the aim of getting the speech partner to do something. The expected response from the speech is an action from the speech partner. In the printed advertisements, instructional speech acts are 
much less used than speech acts in digital media. Ads in the media are often found with click bait as a form of persuasiveness which is expected to be able to generate curiosity from listeners of both audio and audiovisual ads. In digital advertising, the tone used by speakers is intimidating but attracts attention. This is different from print media advertisements which are full of straightforward functions [11]. In printed media advertisements the use of imperative sentences tends to have implications in the form and function of the same. Even though the imperative sentence contains the intention of ordering or asking the speech partner to do something according to what the speaker wants, its use in print media advertisements is still less than optimal [12].

The prohibited directive speech act is a speech act that aims to prevent the speech partner from doing something. In other words, the speaker prohibits the speech partner from committing an act. The speech acts of the prohibited directive are usually expressed by speakers with the same or higher authority than the speech partners. The speech act function of the directive asks the speaker to get something or his request is granted by the speech partner through his speech. The function of the directive speech act is to encourage speech in a voice which tends to be loud with the intention of encouraging the speech partner to do something. The function of the directive speech act invites the intention of the speech partners to act as desired by the speakers collectively. This function can be characterized by courteous speech, ordering, and so on in a subtle degree [13].

In addition to being seen through the context, the form of request directive speech acts tends to be characterized by the use of polite diction, as well as the use of certain lexicons, such as -yuk, mari, and ayo (let or come on). Based on the data findings, the sentence forms used varied, from imperative sentences, interrogative sentences, to news sentences. The imperative indication in advertising speech can be seen in the use of verbs that are still in the form of basic verbs. Even though they use imperative speech, speakers still show a smiling expression when uttering these utterances. It is done to reduce pressure on the speech partners to take the desired action. Hence, the speech partners take action voluntarily without significant pressure.

The function of command directive speech acts includes ordering, directing, and requiring. The form of the prohibition directive speech act has the function of prohibiting and limiting. The function of the licensing act consists of the function of approving and allowing. Finally, the function of advising and suggesting is included in the speech act function of the advice directive. In the form of request directive speech act, there are three functions found. The usual asking function is marked by the use of the word ask or help, a push function which aims to encourage the speech partner to do something. The function of the third request speech act is to invite persuasion to speech partners to do something, especially in this case buying goods or using the services of advertisers. As the implied meaning behind speech, implicatures can also be said to be speech acts, so implicatures have a function which is reflected in the speaker's utterance intentions to the speech partners in a conversation or communication process.

Persuasion texts require deep thinking skills and being able to see from a wide variety of perspectives. Persuasive expression skills prepare and express opinions in clear language to validate one's own ideas, to support ideas using evidence, to anticipate and refute opposing views. Persuasive studies are very relevant to text in advertisements. Advertising is a nonpersonal communication that conveys various messages persuasively from sponsors that clearly influence others. In other words, advertising as a means of community communication is required to be able to influence consumers. 
Advertisements must be prepared using language and speech acts that are as attractive as possible [14]. Good language packaging will improve product image and consumer buying interest in the advertised products because it can significantly influence consumer purchase interest, both from the dimensions of advertising messages, ad text, ad design, ad models, and ad color and music. The implicature function is reflected in the utterance intent expressed by the speaker to the speech partner during the conversation. In this research, the implicature function is implied in the utterances of speakers in advertisements to speech partners or listeners.

\section{Conclusions}

Advertising is a medium that can be used to inform the general public to be interested in the goods or services offered. The language used in advertisements uses language that has hidden meanings to attract people's attention. However, not a few advertisements use straightforward language to attract attention from listeners or even want the ad to be straight to the point. This hidden meaning is studied using a pragmatic study with a discussion of implicatures and produces a variety of data. For instance, advertisements contain many sentences that require a pragmatic study to find out what the real intention is to convey. In the printed media advertisements, the use of imperative sentences which are meaningful sentences telling or prohibiting people to do something is very rarely found in contrast to straightforward digital advertising with the use of imperative sentences such as prohibiting using other products, ordering to buy products from the advertiser, to the point of forcing potential buyers.

Based on the data analysis conducted, the use of informative speech acts is mostly used in printed media advertisements, while speech acts in digital advertisements are more complex and almost all of them exist. Based on the data and analysis performed on advertisements, the sentences used in advertisements prove that interrogative speech is a declarative mode of speech as it has the meaning of conveying information including the expressive implicature function because it is included in a satirical sentence. Indirectly, the sentence insinuates other products or service providers.

\section{References}

[1] A. Bowes and A. Katz, "When sarcasm stings," Discourse Process., 2011.

[2] G. Leech, The Pragmatics of Politeness. 2014.

[3] P. A. Duff, Case study research in applied linguistics. 2012.

[4] E. Sudaryanto, Memet; Sumarwati; Suryanto, "Register Anak Jalanan Kota Surakarta," vol. I, no. April, pp. 514-528, 2014.

[5] B. Clancy and A. O'Keeffe, "Pragmatics," in The Cambridge Handbook of English Corpus Linguistics, 2015.

[6] R. de Beaugrande, "Critical discourse analysis: History, ideology, methodology," Stud. Lang. Capital., 2006.

[7] M. Rohmadi, "Analisis Wacana Pragmatik (Kajian Teori dan Analisanya)," in Analisis Wacana Pragmatik (Kajian Teori dan Analisanya), 2004.

[8] A. Warokka, H. Sjahruddin, S. Sriyanto, E. Noerhartati, and K. Saddhono, "Digital marketing support and business development using online marketing tools: An experimental analysis," Int. J. Psychosoc. Rehabil., vol. 24, no. 1, 2020.

[9] M. Rohmadi, "Kajian Pragmatik Percakapan Guru Dan Siswa Dalam Pembelajaran Bahasa 
Indonesia,” J. Paedagog. Fak. Kegur. dan Ilmu Pendidik. Univ. Sebel. Maret, vol. 14, no. 2 , pp. 23-41, 2014.

[10] M. Picard and L. Velautham, "Developing Independent Listening Skills for English as an Additional Language Students,” Int. J. Teach. Learn. High. Educ., 2016.

[11] A. Bandura, "Social Cognitive Theory of Mass Communication," Media Psychology. 2001.

[12] J. Kahne and B. Bowyer, "The Political Significance of Social Media Activity and Social Networks," Polit. Commun., 2018.

[13] K. Rahardi, "Linguistic Impoliteness in The Sociopragmatic Perspective," J. Hum., 2017.

[14] The Poynter Institute, "Eyetracking the News: A Study of Print and Online Reading," 2008. 